\author{
Michèle Milili · Henedina Antunes \\ Carla Blanco-Betancourt · Ana Nogueiras \\ Eugénia Santos · Júlia Vasconcelos · João Castro e Melo \\ Claudine Schiff
}

\title{
A new case of autosomal recessive agammaglobulinaemia with impaired pre-B cell differentiation due to a large deletion of the IGH locus
}

Received: 30 January 2002 / Accepted: 22 May 2002 / Published online: 12 July 2002

(C) Springer-Verlag 2002

\begin{abstract}
Males with X-linked agammaglobulinaemia (XLA) due to mutations in the Bruton tyrosine kinase gene constitute the major group of congenital hypogammaglobulinaemia with absence of peripheral B cells. In these cases, blockages between the pro-B and pre- $\mathrm{B}$ cell stage in the bone marrow are found. The remaining male and female cases clinically similar to XLA represent a genotypically heterogeneous group of diseases. In these patients, various autosomal recessive disorders have been identified such as mutations affecting IGHM, CD79A, IGLL1 genes involved in the composition of the pre-B cell receptor (pre-BCR) or the $B L N K$ gene implicated in pre-BCR signal transduction. In this paper, we report on a young female patient characterised by a severe non-XLA agammaglobulinaemia that represents a new case of Ig $\mu$ defect. We show that the B cell blockage at the pro-B to pre$\mathrm{B}$ cell transition is due to a large homologous deletion in the IGH locus encompassing the IGHM gene leading to the inability to form a functional pre-BCR. The deletion extends from the beginning of the diversity (D) region to the $I G H G 2$ gene, with all $J H$ segments and IGHM, IGHD, IGHG3 and IGHGI genes missing. Conclusion: alteration in Ig $\mu$ expression seems to be relatively frequent and could account for most of the reported cases of autosomal recessive agammaglobulinaemia.
\end{abstract}

M. Milili · C. Blanco-Betancourt · C. Schiff $(\bowtie)$

Centre d'Immunologie de Marseille-Luminy, case 906,

13288 Marseille cedex 09, France

E-mail: schiff@ciml.univ-mrs.fr

Tel.: + 33-4-91269448

Fax: + 33-4-91269430

H. Antunes · A. Nogueiras

Gastroenterology and Nutrition Unit, Paediatric Department, São Marcos Hospital, Braga, Portugal

E. Santos · J. Vasconcelos · J. Castro e Melo

Serviço de Imunologia, Hospital Geral de Santo António, Porto, Portugal
Keywords Agammaglobulinaemia - B cell blockage · $I G H$ locus $\cdot$ Immunoglobulin gene deletion $\cdot$ Pre-B cell

Abbreviations BET: ethidium bromide $\cdot B T K$ : Bruton tyrosine kinase gene $\cdot I G H$ : immunoglobulin heavy chain locus · pre-BCR: pre-B cell receptor .

$X L A$ : X-linked agammaglobulinaemia

\section{Introduction}

Recurrent infections, mostly respiratory, with pyogenic bacteria are the predominant manifestations of children suffering antibody deficiencies. In some of these patients, early B cell development in the bone marrow is arrested and hypogammaglobulinaemia results from the absence of peripheral B cells. In these cases, chronic diarrhoea could also be observed and constitutes a serious clinical problem. This occurs in X-linked agammaglobulinaemia (XLA), also known as Bruton disease, characterised by defects in the Bruton tyrosine kinase gene (BTK) $[13,14]$ that encodes the cytoplasmic tyrosine kinase btk, involved in signal transduction. In these cases, B cell development is blocked in the bone marrow at the pre- $\mathrm{B}$ cell stage, resulting in the accumulation of CD34+ $\mathrm{CD} 19+$ pro-B cells and in the presence of variable numbers of CD34-CD19+ pre-B cells. Females with a phenotype indistinguishable from XLA have also been described and Conley et al. [2] have estimated that these immunodeficiencies represent $10 \%$ of patients with congenital hypogammaglobulinaemia. The defects behind such autosomal recessive disorders have been recently identified and shown to affect predominantly the pre-B cell receptor (pre-BCR), which is an absolute prerequisite for pro-B to pre-B cell transition and to allow further B cell differentiation [3,12]. This receptor, expressed on pre-B cells is composed of the $\operatorname{Ig} \mu$, the $\Psi \mathrm{L}$ chain (made of $\lambda$-like and $\operatorname{VpreB}$ ) and the $\operatorname{Ig} \alpha / \operatorname{Ig} \beta$ transducing complex [5]. For example, mutations affecting IGHM [12,15], CD79A [10], IGLL1 [9] or 
$B L N K$ that encodes a $\mathrm{B}$ cell linker protein essential for Ig $\mu$ signal transduction [11], have been reported.

In this paper we describe a new case of autosomal recessive agammaglobulinaemia due to a large deletion of the immunoglobulin heavy chain locus (IGH), including the $I G H M$ gene, that results in the absence of a functional pre-BCR.

\section{Case report}

The patient, a 35-month-old girl, was the second child of healthy parents born in the same small village, near Braga, Portugal, who were thought to be non-consanguineous (see below). She had a healthy 6-year older brother. Apart from symmetrical intrauterine growth retardation due to uteroplacental insufficiency, no other significant abnormalities related to family history, pregnancy and delivery were detected. An echocardiogram confirmed a congenital cardiopathy, secundum ASD (atrium secundum, intra-auricular communication) which resolved spontaneously without surgery. At 9 months of age she was referred to the Paediatric Gastroenterology Department because of failure to thrive and chronic diarrhoea during the previous month. Her weight was $5640 \mathrm{~g}(\mathrm{P}<3)$, her height $60 \mathrm{~cm}(\mathrm{P}<3)$ and her head circumference $40.8 \mathrm{~cm}(\mathrm{P}<5)$. Physical examination showed that she was not dehydrated, she had no detectable tonsils and no palpable adenomegaly and revealed that she had elongated fingers (data not shown). According to the Kanawati-McLaren index (0.31), she had no clinical signs of malnutrition.

A routine blood examination showed leucocyte and platelet counts of $27500 / \mathrm{mm}^{3}$ and $345000 / \mathrm{mm}^{3}$, respectively, and haemoglobin at $13.2 \mathrm{~g} / \mathrm{dl}$. Total protein was $5.2 \mathrm{~g} / \mathrm{dl}$ and albumin $3.7 \mathrm{~g} / \mathrm{dl}$. Blood, urine and stool cultures were sterile. TORCH serology and sweat tests were negative. Search in stools for virus, parasites, reducing sugar and fat was negative. Alpha-1 anti-trypsin in stools was $<1.7 \mathrm{mg} / \mathrm{g}$ dry weight (normal $<5.0 \mathrm{mg} / \mathrm{g}$ ). Histology of a duodenal biopsy showed no histological changes but immunocytochemistry revealed a complete absence of B cells and normal numbers of $\mathrm{T}$ cells. The patient responds to BCG and oral poliomyelitis vaccines without any complication.

Her peripheral blood immunological data, determined at 10 months of age, are presented in Table 1. A clear agammaglobulinaemia was evident with a serum $\mathrm{IgG}$ level of $5 \mathrm{mg} / \mathrm{dl}$ and undetectable IgM and IgA. Lymphocyte phenotyping showed the absence of circulating B cells (CD19 or CD20 positive cells), normal numbers of CD4 $\mathrm{T}$ lymphocytes and increased numbers and proportions of NK and CD8 T cells, this latter population showing increased expression of HLA-DR, CD45RO and CD95 activation markers (data not shown).

Table 1. Immunological data

\begin{tabular}{|c|c|c|}
\hline & $\begin{array}{l}\text { Patient (aged } \\
10 \text { months) }\end{array}$ & $\begin{array}{l}\text { Age-matched } \\
\text { controls }\end{array}$ \\
\hline Lymphocyte count $\left(10^{3}\right.$ cells $\left./ \mu \mathrm{l}\right)$ & 1.1 & $3-8$ \\
\hline \multicolumn{3}{|l|}{ Serum immunoglobulins $(\mathrm{mg} / \mathrm{dl})$} \\
\hline $\operatorname{IgM}$ & $<0.1$ & $25-182$ \\
\hline IgG & 5 & $441-880$ \\
\hline $\operatorname{Ig} \mathrm{A}$ & $<0.1$ & $11-117$ \\
\hline \multicolumn{3}{|l|}{ Blood B lymphocytes $(\%)$} \\
\hline CD19 & $<0.01$ & $19-31$ \\
\hline CD20 & $<0.01$ & $19-31$ \\
\hline \multicolumn{3}{|l|}{ Blood T lymphocytes (\%) } \\
\hline CD3 & 84 & $55-79$ \\
\hline $\mathrm{CD} 4+/ \mathrm{CD} 3+$ & 46 & $35-59$ \\
\hline $\mathrm{CD} 8+/ \mathrm{CD} 3+$ & 38 & $16-34$ \\
\hline \multicolumn{3}{|l|}{ Blood NK lymphocytes (\%) } \\
\hline $\mathrm{CD} 3-/ \mathrm{CD} 16+\mathrm{CD} 56+$ & 16 & $4-11$ \\
\hline
\end{tabular}

Since the age of 10 months, she has been treated with intravenous replacement immunoglobulin therapy $(400 \mathrm{mg} / \mathrm{kg}$ every 3 weeks, with pre-administration levels of $300-500 \mathrm{mg} / \mathrm{dl}$ ). During the 25 months follow-up, two episodes of gastroenteritis, a viral rhinitis and an ear infection were diagnosed, which, however, did not require anti-microbial therapy.

The parents gave informed consent for this investigation.

\section{Materials and methods}

Immunoglobulin measurement and cell phenotyping

Serum immunoglobulin IgG, IgA, and IgM were determined by rate nephelometry. Whole peripheral blood and bone marrow mononuclear cells isolated by Ficoll-Hypaque gradient were used for phenotyping. Cell surface antigens were stained with conjugated anti-human monoclonal antibodies and were analysed by flow cytometry. Bone marrow mononuclear cells were stained with FITC-conjugated monoclonal antibodies against CD10, CD20, CD34, CD3, CD4 or phycoerythrin-conjugated monoclonal antibodies against $\mathrm{CD} 19, \mathrm{CD} 8, \mathrm{CD} 16$ and CD56, from Immunotech (France). Phycoerythrin-conjugated anti-Ig $\delta$ and APC-conjugated anti-CD19 were from Pharmingen (France). Biotin-conjugated anti-human Ig $\mu$ chain from Southern Biotechnology (USA) was revealed with PerCP-conjugated Streptavidin (Becton and Dickinson, USA). Peripheral blood B cells were stained with FITC-conjugated monoclonal antibodies against CD19, CD20, CD4, CD8, phycoerythrin-conjugated monoclonal antibodies against CD8, CD16, CD56, PE/Cy5-conjugated monoclonal antibodies against CD3, from Immunotech (France) and from Dako, SA (Denmark), and were haemolysed and fixed (T-prep, Beckman-Coulter) before flow cytometric analysis.

RNA and reverse transcriptase polymerase chain reaction

Total RNA was extracted from total bone marrow cells using TRIzol Reagent (Gibco BRL) as described by Chomczynski and Sacchi [1]. RNA $(2 \mu \mathrm{g})$ was reverse transcribed using the reverse transcriptase Superscript II (Gibco BRL), $1 \mu \mathrm{g}$ of random hexamer (dN6), $1 \mathrm{mM}$ dNTPs and the supplied buffer. For reverse transcriptase-PCR, $1 \mu \mathrm{l}$ of cDNA was amplified for 30 cycles of $30 \mathrm{~s}$ at $94^{\circ} \mathrm{C}, 1 \mathrm{~min}$ at the appropriate temperature and $2 \mathrm{~min}$ at $72^{\circ} \mathrm{C}$ with a final $10 \mathrm{~min}$ extension at $72^{\circ} \mathrm{C}$, using Taq DNA polymerase (BRL) and the primers already described [12]

\section{DNA and DNA-polymerase chain reaction}

Genomic DNA was extracted from peripheral blood mononuclear cells with proteinase $\mathrm{K}$, sodium dodecyl sulphate and phenolchloroform extractions. PCR was performed, as above, using $100 \mathrm{ng}$ of DNA. For semi quantitative analysis, PCRs were carried out during the exponential phase of the DNA amplification. In that case, the exponential phase of each PCR was determined by titration of cycle numbers and by quantities of total DNA. PCR products were analysed on $2 \%$ agarose gels and revealed by ethidium bromide (BET) staining. Quantification was performed using the MacBas software.

\section{Results}

Phenotypic analysis of bone marrow cells

Peripheral blood phenotype of the patient revealed a pure $\mathrm{B}$ cell defect since a profound agammaglobulinaemia with a total absence of peripheral B cells was observed and since the levels and phenotype of $\mathrm{T}$ and 
NK cells did not indicate a T-B-combined immunodeficiency. Thus, we analysed bone marrow B cell subpopulations. A bone marrow sample was obtained when the patient (from now referred as the $\operatorname{Ig} \mu^{\Delta}$ patient, see below) was 24 months old. Total CD19+ patient's B cells were diminished more than three-fold $(13 \%$ versus $43 \%$ in age matched control) and the population of large $\mathrm{B}$ cells, mainly corresponding to proliferating pre-B cells, was nearly absent (Fig. 1A). Gated CD19+ cells were completely negative for surface Ig $\mu$ expression (Fig. 1B) and for $\operatorname{Ig} \delta$ and CD40 expression (data not shown), indicating a total absence of immature and mature B cells in the patient's bone marrow. In contrast, $\mathrm{CD} 34+$ precursors and $\mathrm{CD} 34+\mathrm{CD} 19+$ pro-B cells were within normal limits as compared to an age-matched control (Fig. 1C). Altogether these data indicate that the patient suffered from an early bone marrow B cell blockage, between pro-B and pre-B cell stages.

\section{Molecular analysis}

RT-PCR analysis was performed on total mononuclear bone marrow cells for transcripts expressed during the pro-B to pre-B cell transition, including $\lambda$-like, VpreB, $\operatorname{Ig} \alpha, \operatorname{Ig} \beta$, and Blnk. The resulting PCR products were directly sequenced and were normal (data not shown). In contrast, no transcripts were detected for $\operatorname{IgC} \mu$ specific amplification. This result was confirmed at the DNA level since no amplification could be detected using the $\mu \mathrm{CH} 1$ and $\mu \mathrm{CH} 2$ oligonucleotides (Table 2, Fig. 2) for the patient's DNA. These data indicate that a deletion within the $I G H$ locus, carried by both alleles, was responsible for the patient's phenotype.

To analyse the extent of the DNA deletion, we performed a detailed analysis of the $I G H$ locus by PCR. By using JH5-JH6 and $\delta \mathrm{CH} 2-\delta \mathrm{CH} 3$ primers, we showed that the $J H$ cluster and the $I G H D$ gene respectively were completely missing. Moreover, we mapped the 5 , end of the deletion between the IGHD2-2 and the IGHD3-10 genes within the $I G H D$ locus, since we could amplify the IGHD2-2 and not the IGHD3-10 gene (Fig. 2). Using $\gamma \mathrm{CH} 2$ and $\gamma \mathrm{CH} 3$ oligonucleotides that are common to different $I G H G$ gene sub-classes, we demonstrated that some $I G H G$ genes were present in the patient's genome.
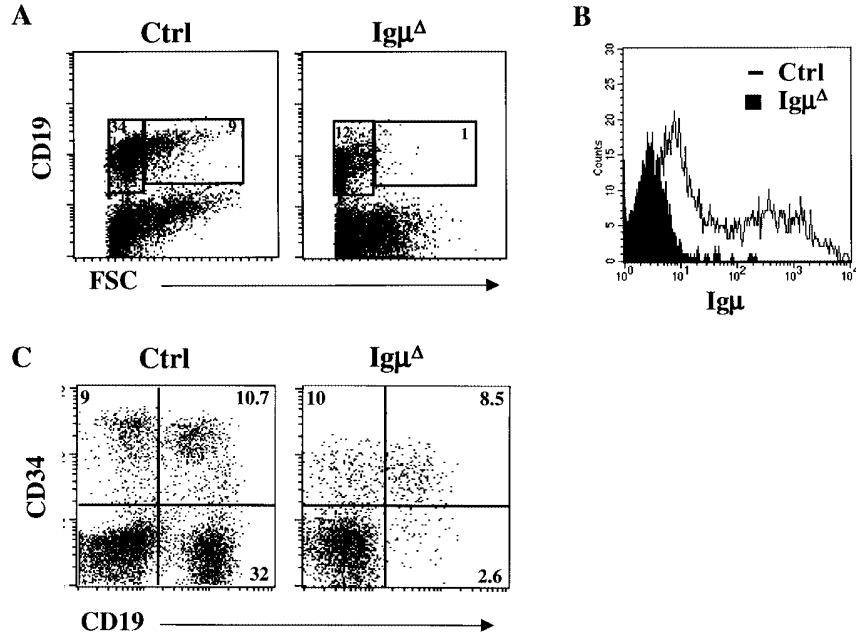

Fig. 1. FACS analysis of bone marrow B cell sub-populations for the $\operatorname{Ig} \mu^{\Delta}$ patient and an age-matched control $(C t r l)$. A Bone marrow mononuclear cells from $\operatorname{Ig}^{\Delta}{ }^{\Delta}$ and an age-matched control were stained with anti-CD19 monoclonal antibody and analysed by flow cytometry. Fluorescence intensity of stained cells is presented as a function of cell size (forward scatter). B Bone marrow mononuclear cells were stained with anti-CD19 and anti-Ig $\mu$ monoclonal antibodies and CD19+ cells, gated and analysed for Ig $\mu$ chain expression. Solid and empty curves represent Ig $\mu^{\Delta}$ patient and age-matched control, respectively. $\mathbf{C}$ Bone marrow mononuclear cells were stained with anti-CD34 and anti-CD19 monoclonal antibodies. Dot plots show precursor $(\mathrm{CD} 34+)$, pro-B $(\mathrm{CD} 34+\mathrm{CD} 19+)$ and pre-B + immature + mature (CD34$\mathrm{CD} 19+$ ) bone marrow $\mathrm{B}$ cell sub-populations

Table 2. Oligonucleotide primers used for DNA-PCR amplification

\begin{tabular}{|c|c|c|c|c|}
\hline Locus & Form & Primers used (5' to $\left.3^{\prime}\right)$ & $\begin{array}{l}\text { Annealing } \\
\text { temperature }\left({ }^{\circ} \mathrm{C}\right)\end{array}$ & $\begin{array}{l}\text { Product } \\
\text { size }(\mathrm{bp})\end{array}$ \\
\hline \multirow[t]{2}{*}{ D 2-2 } & Sense & GATATTGTAGTAGTACCAGCTGC & 66 & \multirow[t]{2}{*}{422} \\
\hline & Antisense & GTAGGATAGCGGCTGCTTCTC & 66 & \\
\hline \multirow[t]{2}{*}{ D3-10 } & Sense & GTATTACTATGGTTCGGGGAG & 62 & \multirow[t]{2}{*}{564} \\
\hline & Antisense & GAAATGACCCAGGAGAGGCTC & 66 & \\
\hline \multirow[t]{2}{*}{ JH5-JH6 } & Sense & GCCGTCTGCTTGCAGTTGGAC & 68 & \multirow[t]{2}{*}{593} \\
\hline & Antisense & CTACAGACACCGCTCCTGAGAC & 70 & \\
\hline \multirow[t]{2}{*}{$\mu \mathrm{CH} 1-\mu \mathrm{CH} 2$} & Sense & AGGGAGTGCATCCGCCCCAAC & 68 & \multirow[t]{2}{*}{647} \\
\hline & Antisense & CTTTGATGGTCAGTGTGCTGGTC & 70 & \\
\hline \multirow[t]{2}{*}{$\delta \mathrm{CH} 2-\delta \mathrm{CH} 3$} & Sense & GCAGTGCAGGACCTGTGGCTC & 70 & \multirow[t]{2}{*}{577} \\
\hline & Antisense & GCCAGACACCTCACACAGGAGC & 72 & \\
\hline \multirow{2}{*}{$\gamma \mathrm{CH} 2-\gamma \mathrm{CH} 3$} & Sense & GGAGGTGCATAATGCCAAGACAAAG & 74 & \multirow[t]{2}{*}{360} \\
\hline & Antisense & TTGACCAGGCAGGTCAGGCTGAC & 74 & \\
\hline \multirow[t]{2}{*}{$\mathrm{S} \gamma 1$} & Sense & GCAGAGCATCACAACGTCAGC & 66 & \multirow[t]{2}{*}{261} \\
\hline & Antisense & GAGCTAGTCCTGCTCACCTTC & 66 & \\
\hline \multirow[t]{2}{*}{$\gamma 2 \mathrm{H}-\gamma 2 \mathrm{CH} 2$} & Sense & GCGCAAATGTTGTGTCGAGT & 60 & \multirow[t]{2}{*}{175} \\
\hline & Antisense & CGGTCCTGCCACAGGTGG & 62 & \\
\hline \multirow[t]{2}{*}{ VpreB } & Sense & CTGAGATATTTCTCACAATCAGAC & 66 & \multirow[t]{2}{*}{284} \\
\hline & Antisense & TCTTCCATGACAGTCTCTCCAAG & 68 & \\
\hline
\end{tabular}




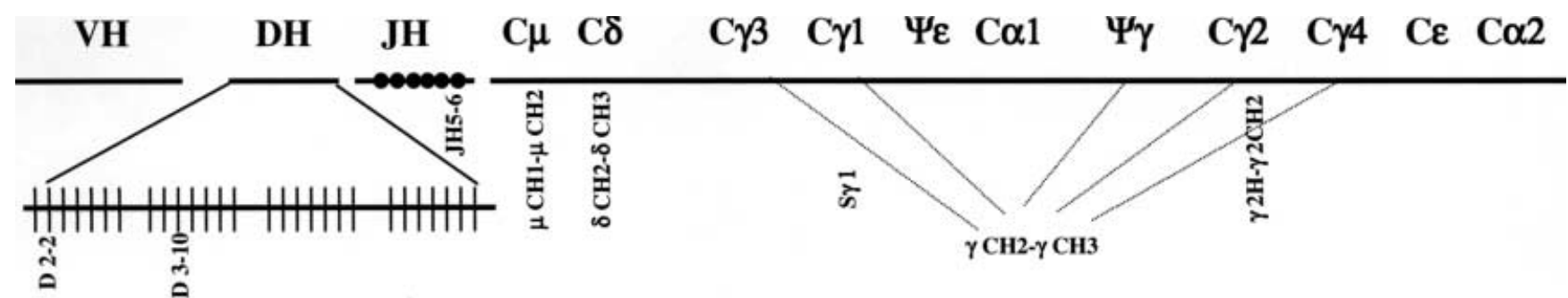

deletion
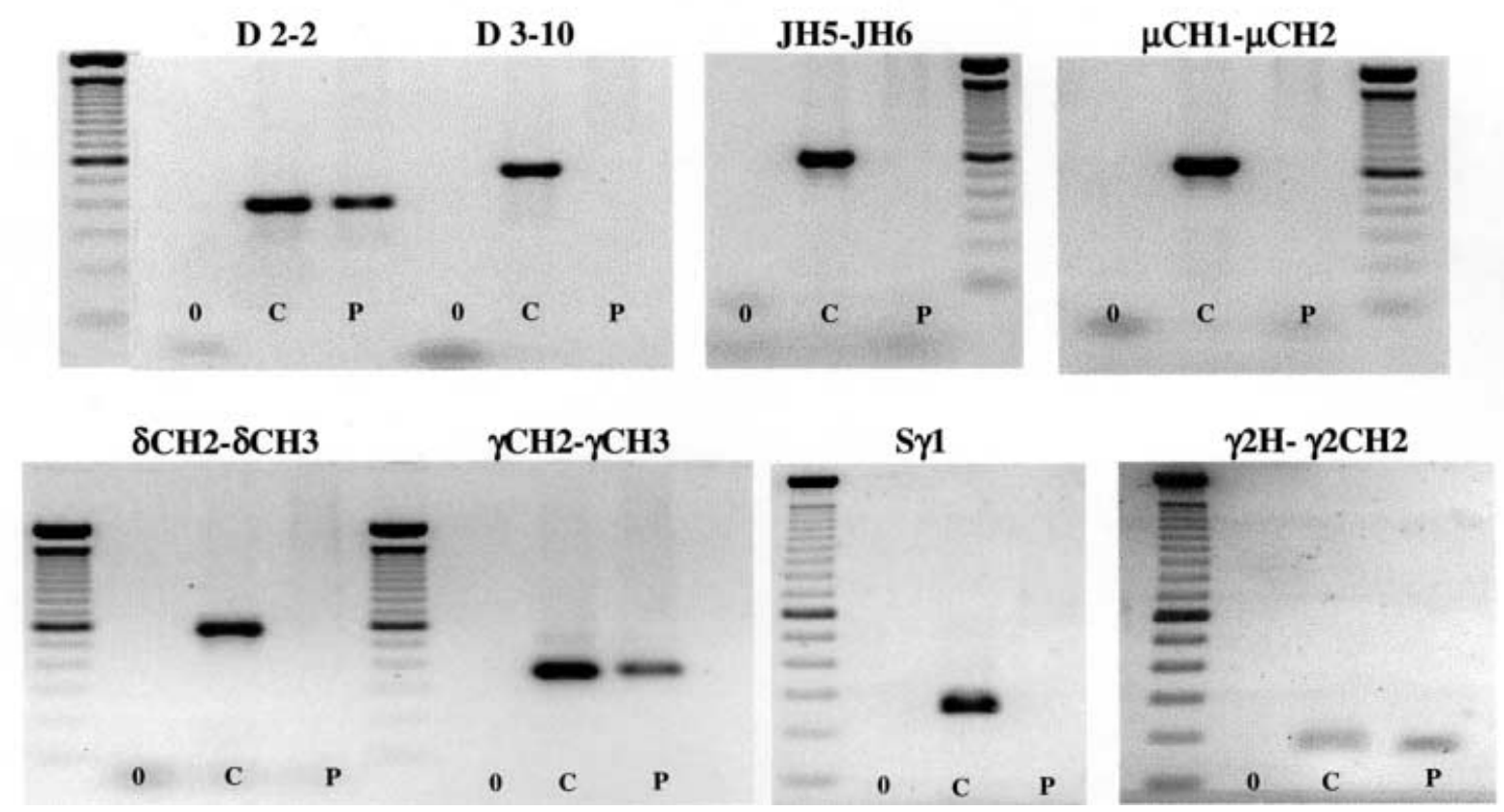

Fig. 2. Molecular analysis of the patient's gene defect. Schematic representation (top) of the human $I G H$ locus and localisation of the primers used for DNA amplification. Extent of the $\operatorname{Ig} \mu^{\Delta}$ patient DNA deletion is shown. PCR amplification (bottom) of the $\operatorname{Ig} \mu^{\Delta}$ patient DNA using the indicated oligonucleotides (see Table 2). 0 , $\mathrm{C}$ and $\mathrm{P}$ lanes correspond to PCR without DNA, control DNA and $\operatorname{Ig} \mu^{\Delta}$ patient DNA, respectively. Amplified DNA products were separated on $2 \%$ agarose gels and revealed by BET staining

Using specific primers in the $I G H G 1$ switch region $(\mathrm{S} \gamma 1)$ or in the hinge region of the IGHG2 gene $(\gamma 2 \mathrm{H}$ and $\gamma 2 \mathrm{CH} 2$ ), we finally demonstrated that the 3' end of the DNA deletion was located between the IGHGI and the $I G H G 2$ genes (Fig. 2). The size of the DNA deletion was estimated to be between 165 to $265 \mathrm{~kb}$ [6].

Family studies

The PCR results obtained for the $\operatorname{Ig} \mu^{\Delta}$ patient suggested the presence of a large homologous DNA deletion of familial origin. A semi-quantitative PCR was performed using VpreB and Ig $\mu$ specific primers on the DNA extracted from peripheral blood mononuclear cells of the father, mother, brother and a healthy donor (Fig. 3A). Since $V P R E B$ is a unique gene in the human genome [4]

it was used to quantify Ig $\mu$ PCR products. The results clearly demonstrated that the DNA from both the father and the mother contained only one copy of the functional IGHM gene (Fig. 3B). In contrast, DNA of the brother as well as control DNA contained two copies of the IGHM allele (Fig. 3B). The patient's brother was therefore homozygous for the functional IGHM allele.

\section{Discussion}

Approximately $85 \%$ of patients with congenital hypogammaglobulinaemia and absent peripheral B cells are males with XLA due to mutations in the $B T K$ gene. The remaining $15 \%$ of cases, clinically identical to XLA, are still a heterogeneous group. Some mutations have been already identified, especially in components of the preBCR, such as IGHM [12,15], IGLL1 [9], CD79A [10], or $B L N K$ [11] that result in impaired pre-B cell differentiation. However, alteration in Ig $\mu$ expression seems to be relatively frequent. For example, Yel et al. [15] described three different mutations in the $I G H$ locus. For one consanguineous family, the affected patients had a DNA deletion covering 75-100 kb that encompassed the diversity genes $(\mathrm{DH})$, the $\mathrm{JH}$ cluster and the IGHM gene. 
Fig. 3. Molecular analysis of family's patient DNA at the $I G H$ locus. A PCR was performed on DNA extracts from healthy donor's peripheral blood mononuclear cells $(C)$, father $(F)$, mother $(M)$ brother $(B)$ and patient $(P)$ using $\mu \mathrm{CH} 1-\mu \mathrm{CH} 2$ and VpreB specific primers (see Table 2). 0 corresponds to PCR without DNA. Amplified DNA products were separated on $2 \%$ agarose gels and revealed by BET staining. B For each DNA, Ig $\mu$ specific amplification is quantified according the VpreB amplification

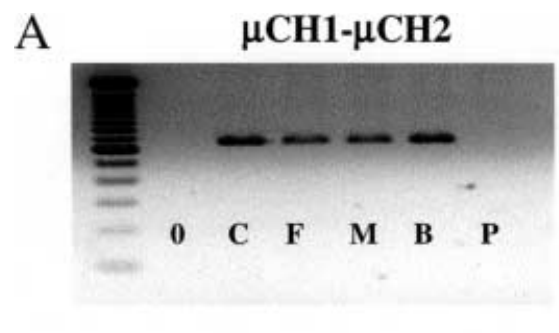

B

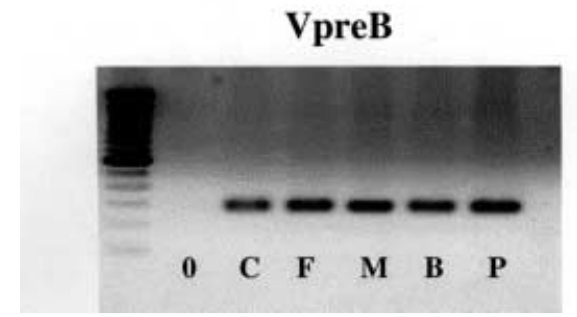

$\mu \mathrm{CH} 1-\mu \mathrm{CH} 2 / \mathrm{VpreB}$

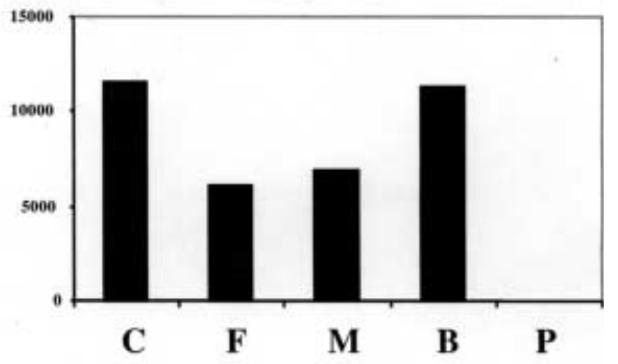

For another consanguineous family, the alteration corresponded to a homozygous single $\mathrm{G}$ to $\mathrm{A}$ base pair substitution at the -1 position of the alternative splice site used to produce the membrane form of the Ig $\mu$ transcript. This mutation would inhibit the production of the membrane Ig $\mu$ chain. It was also reported that a boy, who did not suffer from a $B T K$ alteration, had a heterozygous alteration of the IGHM gene. In this case, a single base pair substitution affecting an invariant cysteine residue in the $\mathrm{CH} 4$ domain of the IGHM chain for one allele, coupled to a large deletion of the $I G H$ locus on the other allele, was detected. We have also reported the case of a girl, referred to as the $\operatorname{Ig} \mu^{-/-}$patient $[7,12]$, in whom we identified a cytosine insertion at the beginning of the $\mathrm{CH} 1$ exon of the IGHM gene, resulting in a stop codon at position 48 , and in the absence of Ig $\mu$ chain expression. The patient reported in this paper, designated as the $\operatorname{Ig} \mu^{\Delta}$ case [8], with a large 165 to $265 \mathrm{~kb}$ homologous deletion of the $I G H$ locus encompassing the IGHM gene, represents a new case of $\operatorname{Ig} \mu$ defect. Altogether we can conclude that Ig $\mu$ alterations account for most of the reported cases of autosomal recessive agammaglobulinemia. These observations also emphasise the requirement of signalling via a functional pre-BCR to ensure normal early B cell differentiation. Moreover, the absence of $\operatorname{Ig} \mu$ chains in $\operatorname{Ig} \mu^{-/-}$and $\operatorname{Ig} \mu^{\Delta}$ patients, has provided an opportunity to elucidate the role of Ig $\mu$ in selecting the antibody repertoire in humans [8].

Along with a better understanding of B cell biology and its developmental defects, identification of such genetic alterations may open the way for new clinical treatments, including somatic gene therapy. Moreover it provides a basis for a more accurate diagnosis, comprising the identification of carrier status, prenatal testing and counselling.

Acknowledgements This work was supported by CNRS (Centre National de la Recherche Scientifique) and INSERM (Institut National de la Santé et de la Recherche Médicale).

\section{References}

1. Chomczynski P, Sacchi N (1987) Single-step method of RNA isolation by acid guanidium thiocyanate-phenol-chloroform extraction. Anal Biochem 162: 156-159

2. Conley ME (1992) Molecular approaches to analysis of X-linked immunodeficiencies. Annu Rev Immunol 10: 215-238

3. Conley ME, Rohrer J, Rapalus L, Boylin EC, Minegishi Y (2000) Defects in early B-cell development: comparing the consequences of abnormalities in pre-BCR signaling in the human and the mouse. Immunol Rev 178: 75-90

4. Frippiat JP, Williams SC, Tomlinson IM, Cook GP, Cherif D, Le Paslier D, Collins JE, Dunham I, Winter G, Lefranc MP (1995) Organization of the human immunoglobulin lambda light-chain locus on chromosome 22q11.2. Hum Mol Genet 4: 983-991

5. Guelpa-Fonlupt V, Bossy D, Alzari P, Fumoux F, Fougereau M, Schiff C (1994) The human pre-B cell receptor: structural constraints for a tentative model of the pseudo-light (psi L) chain. Mol Immunol 31: 1099-1108

6. Lefranc MP (2001) Nomenclature of the human immunoglobulin heavy (IGH) genes. Exp Clin Immunogenet 18: 100116

7. Meffre E, LeDeist F, de Saint-Basile G, Deville A, Fougereau M, Fischer A, Schiff C (1996) A human non-XLA immunodeficiency disease characterized by blockage of B cell development at an early proB cell stage. J Clin Invest 98: 1519-1526

8. Meffre E, Milili M, Blanco-Betancourt C, Antunes $\mathrm{H}$, Nussenzweig MC, Schiff C (2001) Immunoglobulin heavy chain expression shapes the B cell receptor repertoire in human B cell development. J Clin Invest 108: 879-886

9. Minegishi Y, Coustan-Smith E, Wang YH, Cooper MD, Campana D, Conley ME (1998) Mutations in the human lambda5/14.1 gene result in B cell deficiency and agammaglobulinemia. J Exp Med 187: 71-77

10. Minegishi Y, Coustan-Smith E, Rapalus L, Ersoy F, Campana D, Conley ME (1999a) Mutations in Igalpha (CD79a) result in a complete block in B-cell development. J Clin Invest 104: 1115-1121

11. Minegishi Y, Rohrer J, Coustan-Smith E, Lederman HM, Pappu R, Campana D, Chan AC, Conley ME (1999b) An essential role for BLNK in human B cell development. Science 286: 1954-1957

12. Schiff C, Lemmers B, Deville A, Fougereau M, Meffre E (2000) Autosomal primary immunodeficiencies affecting human bone marrow B cell differentiation. Immunol Rev 178: 91-98 
13. Tsukada S, Saffran DC, Rawlings DJ, Parolini O, Allen RC, Klisak I, Sparkes RS, Kubagawa H, Mohandas T, Quan S et al (1993) Deficient expression of a B cell cytoplasmic tyrosine kinase in human X-linked agammaglobulinemia. Cell 72: 279290

14. Vetrie D, Vorechovsky I, Sideras P, Holland J, Davies A, Flinter F, Hammarstrom L, Kinnon C, Levinsky R, Bobrow M et al (1993) The gene involved in X-linked agammaglobulina- emia is a member of the src family of protein-tyrosine kinases. Nature 361: 226-233

15. Yel L, Minegishi Y, Coustan-Smith E, Buckley RH, Trubel H, Pachman LM, Kitchingman GR, Campana D, Rohrer J, Conley ME (1996) Mutations in the mu heavy-chain gene in patients with agammaglobulinemia. N Engl J Med 335: 15231525 